\title{
Crowded Household, Subdivided Flats, and Dilapidated Housing Are Risk Factors of Bedbug (Cimex Lectularius and Cimex Hemipterus) Infestation: a Cross-sectional Study of Hong Kong Households
}

\section{Eddy Hin Chung Fung ( $\nabla$ edfung98@gmail.com )}

The Chinese University of Hong Kong The Jockey Club School of Public Health and Primary Care https://orcid.org/0000-0002-2410-4037

\section{Hung Wong}

The Chinese University of Hong Kong Department of Social Work

\section{Siu Wai Chiu}

The Chinese University of Hong Kong School of Life Sciences

Jerome Ho Lam Hui

The Chinese University of Hong Kong School of Life Sciences

Hon Ming Lam

The Chinese University of Hong Kong School of Life Sciences

\section{Roger Yat-nork Chung}

The Chinese University of Hong Kong The Jockey Club School of Public Health and Primary Care

\section{Samuel Yeung-shan Wong}

The Chinese University of Hong Kong The Jockey Club School of Public Health and Primary Care

\section{Siu Ming Chan}

The Chinese University of Hong Kong Department of Social Work

\section{Research article}

Keywords: Bedbug, dilapidated housing, crowded housing, social justice, health equity, risk factors, Hong Kong

Posted Date: November 3rd, 2020

DOI: https://doi.org/10.21203/rs.3.rs-80113/v1

License: (c) (i) This work is licensed under a Creative Commons Attribution 4.0 International License. Read Full License 


\section{Abstract}

Background: Bedbugs have been a neglected issue globally, disproportionately affecting low-income households. The features of many deprived housing units in Hong Kong provide suitable habitats for bedbug infestations. This study aims to identify the housing risk factors for bedbug infestations in Hong Kong.

Methods: Using a cross-sectional study design, online self-reported questionnaires in Chinese were distributed between June 2019 to July 2020. Data collected were socio-demographics, crowded household condition, housing type, dilapidated housing features, and frequency of noticing bedbugs in the participant's place of residence in the past year. The latter was transformed into a dichotomous dependent variable, "bedbug infestation". Weighted bivariate and multivariate analysis using binary logistic regression were performed on SPSS 24.

Results: The study sampled $\mathrm{N}=696$ participants, $63.7 \%$ have had bedbug infestations. Bivariate analysis shows a positive correlation between the number of dilapidated housing features and bedbug infestation $(\mathrm{OR}=1.28,95 \% \mathrm{Cl} 1.18-1.39, \mathrm{p}<0.001)$. $\mathrm{N}=663$ were included in the multivariate analysis. Those aged 45$64(\mathrm{OR}=2.53,95 \% \mathrm{Cl} 1.30-4.91, \mathrm{p}=0.006)$ and have primary education or below $(\mathrm{OR}=9.43,95 \% \mathrm{Cl} 3.12$ $28.44, p<0.001$ ) have significantly greater odds of bedbug infestation compared to their respective reference groups, $\geq 65$ and tertiary education. Having monthly household income $\leq$ HKD30,000 (OR=1.69, $95 \% \mathrm{Cl} 1.15-2.5, \mathrm{p}=0.008)$ and living in subdivided flats $(\mathrm{OR}=16.53,95 \% \mathrm{Cl} 1.01-269.72, \mathrm{p}=0.049)$ and crowded household $(\mathrm{OR}=1.55,95 \% \mathrm{Cl} 1.06-2.28, \mathrm{p}=0.024)$ increases the odds of bedbug infestation. Dilapidated housing features that significantly increase the odds of bedbug infestation are having second-hand furniture $(\mathrm{OR}=2.97,95 \% \mathrm{Cl} 1.16-7.58, \mathrm{p}=0.023)$, housing cleanliness issues $(\mathrm{OR}=2.66,95 \% \mathrm{Cl}$ 1.13-6.25, $p=0.024)$, presence of bedbugs in neighbouring residential units $(\mathrm{OR}=3.32,95 \% \mathrm{Cl} 1.57-7.04$, $p=0.002)$, and presence of bedbugs on the streets $(O R=1.9,95 \% \mathrm{Cl} 1.12-3.23, p=0.018)$.

Conclusions: Crowded household, subdivided flats, and dilapidated housing are risk factors for bedbug infestations. To better control bedbug infestations, there needs to be a shift from viewing infestations as a personal hygiene to a public health issue. Efforts and policies should focus on addressing the housing risk factors identified in this study and prioritise vulnerable groups such as the elderly, low education level, low-income groups, and occupants of subdivided flats.

\section{Background}

Bedbugs (Cimex lectularius and Cimex hemipterus) are nocturnal ectoparasites that feed on human blood (1). The United States Environmental Protection Agency (US EPA) has deemed bedbugs to be a "pest of significant public health importance" (2). One inseminated female bedbug can start an infestation alone by laying $200-500$ eggs in a lifetime at a rate of $5-15$ eggs a day $(1,3,4)$. Bedbug infestations occur when their population grows out of control causing adverse health effects $(2,5,6,7)$. 
Bedbug bites usually occur in a linear pattern on exposed skin while the host is asleep or still, these usually result in multiple itchy sores where bites occur $(7,8,9,10)$. In severe cases, the bites may result in bullous eruptions (11) and excessive blood lost to bloodmeals may result in anaemia $(7,9)$. Bedbugs have the potential to act as vectors for over 40 diseases, although no outbreaks have been attributed to them so far $(7,12,13)$. Bedbug infestations may result in a broad range of psychosocial disorders including anxiety, depression, and insomnia (14).

Bedbug infestations pose a significant economic burden to households and businesses $(5,15)$. In 2019, the median monthly household income for all households in Hong Kong is HKD28,700 (around USD3,700) (16). Hiring a professional exterminator in Hong Kong per household infestation typically ranges from HKD3,000 to 30,000 (around USD390 to 3,900) depending on the infestation severity, treatment types, living floor area, and other factors. For businesses or facilities such as hotels or hospitals, the cost may be upwards of HKD200,000 (around USD26,000). Low-income households may not afford to hire exterminators or replace infested belongings.

Reported since the 1990s, the global bedbug resurgence has been attributed to several factors including human population growth and urbanisation $(6,7,17)$. These factors strain housing systems leading to more deprived housing with dilapidated housing features that provide favourable conditions for bedbug infestation and spread such as cracks in walls, peeling wallpaper, and crowded housing $(5,18,19)$. The effect of different building types on the risk of bedbug infestation is worth further investigation since certain building characteristics may pose different risks (20).

Having the world's most expensive housing market (21), the housing situation in Hong Kong offers a unique set of environmental factors that are hypothesized to facilitate the local and international spread of bedbug, these include crowded living environments, dilapidated housing, and vastly different housing situation for those who can afford it versus those who cannot $(22,23,24)$.

Bedbug infestations are neglected in Hong Kong despite being a public health threat since 1. Bedbugs are perceived to pose an insignificant health concern compared to other pests such as mosquitos; 2 . Those affected by bedbugs are unlikely to report or seek help for several reasons such as shame, and the lack of means or know-how; and 3. Bedbug infestations are perceived as a personal hygiene instead of a public health issue, shifting the burden of action to individual households rather than the collective efforts of society $(25,26)$.

This study aims to identify the housing risk factors associated to bedbug infestations in Hong Kong.

\section{Methods}

This study used a population-based cross-sectional study design and was conducted in the Hong Kong Special Administrative Region (HKSAR), China.

\section{Data collection and sampling method}


Data was collected using online self-reported questionnaires in Chinese, it was later translated into English (Additional file 1). Data collection occurred between June 2019 to July 2020. Google forms was used to create the questionnaire, its electronic link was broadcast on discussion forums and social media pages of different districts in Hong Kong. Participants were eligible to participate if they lived in Hong Kong and were aged 18 or above. $\mathrm{N}=696$ participants voluntarily completed the questionnaire. G*Power 3.1 was used to calculate the minimum required sample size $(n=617)$ for the multivariate binary logistic regression (27).

\section{Measurements}

For the question, "In the past year, how often did you see bedbugs in your place of residence?", responses ranged from "never" to "very often" on a five-point Likert scale. This variable was transformed into a dichotomous dependent variable, "bedbug infestation", with "never" being "no" and all other responses being "yes". A picture of a bedbug was provided to remind participants of its appearance and minimise its erroneous recognition.

Crowded household was measured using a pseudo quantitative method. Participants were asked whether they felt that their residence lacked space or is crowded (given the variable name "feeling crowded"), their living floor area $\left(\mathrm{ft}^{2}\right)$, and household size. Data from these variables were used to compute the dichotomous variable "crowded household" defined as those who felt that their residence lacked space or is crowded, or those with living floor area per capita $\leq 120 \mathrm{ft}^{2} /$ person. The cut-off of $\leq 120 \mathrm{ft}^{2} /$ person was chosen since less than $25 \%$ of the sample met the criteria. Living floor area per capita was computed by taking the upper bounds of each interval responses for living floor area and dividing that by the household size. For living floor area of $>900 \mathrm{ft}^{2}$, the upper bound was taken as $1200 \mathrm{ft}^{2}$, and household size $\geq 5$ was taken as 5 .

Participants selected their housing type and dilapidated housing features from lists created based on the literature. Participants' sex, age, education level, monthly household income (HKD), and district were also collected. All variables were collected as categorical variables.

Participants had the option to leave their contact information if they were willing to participate in future bedbug related research. $\mathrm{N}=7$ participants were contacted, and the researchers visited their residence to make observations and take photographs of their housing situation within the study period.

\section{Statistical analysis}

A choropleth map of self-reported bedbug infestation cases by district was made. Data analysis was performed using IBM SPSS 24 . Weighting by age and sex was applied to the analysis using census data for the end of 2019.

Bivariate logistic regression using chi-square test for categorical variables was used to identify variables associated with bedbug infestation. All variables were considered for inclusion in the multivariate logistic regression to investigate their effects on the odds of the bedbug infestation. Covariates were entered 
using the forward conditional method if $p<0.05$ and retained if $p<0.1$. Effect estimates for the covariates in the bivariate and multivariate analysis are presented as odds ratio (OR) with their corresponding $95 \%$ confidence interval $(\mathrm{Cl})$. Statistical significance was considered if $\mathrm{p}<0.05$.

Hosmer-Lemeshow goodness-of-fit test and multicollinearity diagnostics were performed on the final model of the multivariate regression. The model does not violate the goodness-of-fit assumption if $p>$ 0.05 . Multicollinearity was considered if the covariates had variance inflation factors (VIF) $\geq 10$, or their absolute value of the Pearson correlation coefficient $|r| \geq 0.7$ (28).

\section{Results}

The questionnaire received $\mathrm{N}=696$ participants; they were all included in the analysis. The sample size included in the multivariate regression after listwise deletion of missing variables is $N=663(95.3 \%)$, this is beyond the minimum required sample size of $617 . \mathrm{N}=7$ underwent follow-up visits, Figs. 6 to 10 were selected photographs taken at their place of residence.

Table 1

Frequency of self-reported bedbug infestation among participants

\begin{tabular}{|lcc|}
\hline $\begin{array}{l}\text { In the past year, how often did you see bedbugs in your place of } \\
\text { residence? } \mathbf{( N = 6 6 3 )}\end{array}$ & $\begin{array}{l}\text { Weighted } \\
\text { frequency (\%) }\end{array}$ & $95 \% \mathbf{C l}$ \\
\hline Very often & $100(15.1)$ & $12.3-$ \\
\hline Often & $93(14.1)$ & 17.8 \\
\hline Sometimes & $92(13.9)$ & 16.7 \\
\hline Rarely & & $11.3-$ \\
& $137(20.6)$ & 17.6 \\
\hline Never & & 23.7 \\
\hline Bedbug infestation $(\mathrm{N}=663)$ & $241(36.3)$ & $32.6-$ \\
\hline Yes & & 39.9 \\
\hline No & Weighted & $95 \% \mathrm{Cl}$ \\
\hline
\end{tabular}

In Table 1, responses for the question "In the past year, how often did you see bedbugs in your place of residence?" were transformed into the variable "bedbug infestation" with "never" being "no" and all other responses being "yes", $n=422(63.7 \%)$ have experienced bedbug infestation in the past year. 


\section{Choropleth map}

Figure 1 shows the number of self-reported bedbug infestation cases in Hong Kong by district between June 2019 to July 2020. Kwai Tsing, Kwun Tong, Sham Shui Po, Kowloon City and Shatin districts had the highest number of reported bedbug infestations. The distribution of self-reported bedbug infestations was concentrated around the Kowloon region. Due to the small number of responses in some districts, the 18 districts were regrouped into 3 regions for analysis in bivariate and multivariate regression.

\section{Bivariate analysis}


Table 2

Bivariate analysis between bedbug infestation and participant characteristics

\begin{tabular}{|c|c|c|c|}
\hline & $\begin{array}{l}\text { Weighted bedbug } \\
\text { infestation (\%) }\end{array}$ & $\begin{array}{l}\text { OR }(95 \% \\
\mathrm{Cl})^{*}\end{array}$ & $\begin{array}{l}\text { p- } \\
\text { value* }\end{array}$ \\
\hline \multicolumn{4}{|l|}{$\operatorname{Sex}(N=662)$} \\
\hline Female (ref.) & $228(63.3)$ & $\begin{array}{l}1.04(0.76- \\
1.44)\end{array}$ & 0.788 \\
\hline Male & $194(64.2)$ & & \\
\hline Age $(N=663)$ & & & 0.006 \\
\hline $0-24$ & $72(52.2)$ & $\begin{array}{l}0.4(0.24- \\
0.68)\end{array}$ & $<.001$ \\
\hline $25-44$ & $126(64.3)$ & $\begin{array}{l}0.66(0.4- \\
1.09)\end{array}$ & 0.101 \\
\hline $45-64$ & $137(65.2)$ & $\begin{array}{l}0.68(0.41- \\
1.11)\end{array}$ & 0.124 \\
\hline$\geq 65$ (ref.) & $87(73.1)$ & & \\
\hline Education level $(\mathrm{N}=664)$ & & & $<.001$ \\
\hline Primary education or below & $63(92.6)$ & $\begin{array}{l}10.56 \\
(4.11- \\
27.11)\end{array}$ & $<0.001$ \\
\hline Secondary education & $152(69.7)$ & $\begin{array}{l}1.87(1.32- \\
2.67)\end{array}$ & $<.001$ \\
\hline Tertiary education (ref.) & $208(55)$ & & \\
\hline Monthly household income $(\mathrm{N}=664)$ & & & $<.001$ \\
\hline$<$ HKD10,000 & $74(74.7)$ & $\begin{array}{l}3.13(1.56- \\
6.27)\end{array}$ & 0.001 \\
\hline HKD10,000-30,000 & $188(73.7)$ & $\begin{array}{l}2.99(1.65- \\
5.43)\end{array}$ & $<.001$ \\
\hline HKD30,001-50,000 & $82(52.9)$ & $\begin{array}{l}1.2(0.65- \\
2.21)\end{array}$ & 0.566 \\
\hline HKD50,001-80,000 & $52(52.5)$ & $\begin{array}{l}1.18(0.61- \\
2.27)\end{array}$ & 0.629 \\
\hline$>\mathrm{HKD} 80,000$ & $27(48.2)$ & & \\
\hline $\begin{array}{l}\text { Monthly household income } \leq \text { HKD } 30,000(\mathrm{No}= \\
\text { ref.) }(\mathrm{N}=663)\end{array}$ & $261(73.9)$ & $\begin{array}{l}2.63(1.9- \\
3.64)\end{array}$ & $<.001$ \\
\hline
\end{tabular}




\begin{tabular}{|c|c|c|c|}
\hline & $\begin{array}{l}\text { Weighted bedbug } \\
\text { infestation (\%) }\end{array}$ & $\begin{array}{l}\mathrm{OR}(95 \% \\
\mathrm{Cl}) *\end{array}$ & $\begin{array}{l}\text { p- } \\
\text { value* }\end{array}$ \\
\hline Region (New Territories Region = ref.) & & & 0.013 \\
\hline Hong Kong Island Region ( $\mathrm{N}=662)$ & $33(70.2)$ & $\begin{array}{l}1.62(0.84- \\
3.11)\end{array}$ & 0.149 \\
\hline Kowloon Region ( $\mathrm{N}=663$ ) & $179(69.6)$ & $\begin{array}{l}1.62(1.16- \\
2.28)\end{array}$ & 0.005 \\
\hline New Territories Region ( $N=662$ ) & $210(58.7)$ & & \\
\hline Crowded household $(\mathrm{N}=663)$ & $177(72)$ & $\begin{array}{l}1.81(1.29- \\
2.55)\end{array}$ & $<.001$ \\
\hline Feeling crowded ( $N=662)$ & $142(72.1)$ & $\begin{array}{l}1.69(1.18- \\
2.43)\end{array}$ & 0.004 \\
\hline $\begin{array}{l}\text { Living floor area per capita } \leq 120 \mathrm{ft}^{2} / \text { person ( } \mathrm{No}= \\
\text { ref.) }(\mathrm{N}=663)\end{array}$ & $89(72.4)$ & $\begin{array}{l}1.64(1.07- \\
2.54)\end{array}$ & 0.024 \\
\hline Living floor area $\left(\mathrm{ft}^{2}\right)(\mathrm{N}=660)$ & & & 0.001 \\
\hline$<300$ & $118(75.2)$ & $\begin{array}{l}2.63(1.33- \\
5.21)\end{array}$ & 0.005 \\
\hline $301-600$ & $209(63.7)$ & $\begin{array}{l}1.53(0.82- \\
2.86)\end{array}$ & 0.177 \\
\hline $601-900$ & $70(53.8)$ & $\begin{array}{l}1.02(0.52- \\
2.01)\end{array}$ & 0.947 \\
\hline$>900$ & $24(53.3)$ & & \\
\hline Household size ( $N=663)$ & & & $<0.001$ \\
\hline 1 & $59(84.3)$ & $\begin{array}{l}2.15(0.98- \\
4.71)\end{array}$ & 0.057 \\
\hline 2 & $83(62.4)$ & $\begin{array}{l}0.66(0.38- \\
1.17)\end{array}$ & 0.155 \\
\hline 3 & $106(62.4)$ & $\begin{array}{l}0.66(0.38- \\
1.14)\end{array}$ & 0.134 \\
\hline 4 & $106(54.4)$ & $\begin{array}{l}0.47(0.28- \\
0.8)\end{array}$ & 0.005 \\
\hline$\geq 5$ & $68(71.6)$ & & \\
\hline \multicolumn{4}{|l|}{ Housing type (No = ref.) } \\
\hline Public rental housing $(\mathrm{N}=664)$ & $205(71.4)$ & $\begin{array}{l}1.82(1.31- \\
2.53)\end{array}$ & $<.001$ \\
\hline
\end{tabular}




\begin{tabular}{|c|c|c|c|}
\hline & $\begin{array}{l}\text { Weighted bedbug } \\
\text { infestation (\%) }\end{array}$ & $\begin{array}{l}\mathrm{OR}(95 \% \\
\mathrm{Cl})^{*}\end{array}$ & $\begin{array}{l}\text { p- } \\
\text { value* }\end{array}$ \\
\hline Home ownership scheme ( $N=663)$ & $45(51.7)$ & $\begin{array}{l}0.56(0.35- \\
0.88)\end{array}$ & 0.011 \\
\hline Private housing (whole unit) ( $N=662$ ) & $129(56.3)$ & $\begin{array}{l}0.62(0.44- \\
0.86)\end{array}$ & 0.004 \\
\hline Subdivided flats $(N=664)$ & $25(96.2)$ & $\begin{array}{l}29.11(1.83- \\
461.92)\end{array}$ & 0.017 \\
\hline Village house $(\mathrm{N}=662)$ & $17(56.7)$ & $\begin{array}{l}0.73(0.35- \\
1.51)\end{array}$ & 0.391 \\
\hline Non-profit-making organisation houses $(\mathrm{N}=663)$ & $1(50)$ & $\begin{array}{l}1.11(0.05- \\
25.26)\end{array}$ & 0.946 \\
\hline $\begin{array}{l}\text { Dorm room (government, worker, disciplined } \\
\text { services) }(\mathrm{N}=663)\end{array}$ & $1(50)$ & $\begin{array}{l}0.39(0.02- \\
7.2)\end{array}$ & 0.525 \\
\hline Wooden house $(\mathrm{N}=663)$ & $0(0)$ & & 1 \\
\hline \multicolumn{4}{|l|}{ Dilapidated housing features ( $\mathrm{No}=$ ref.) } \\
\hline $\begin{array}{l}\text { Lack privacy (within the house and between } \\
\text { neighbours) }(N=662)\end{array}$ & $78(69.6)$ & $\begin{array}{l}1.37(0.89- \\
2.13)\end{array}$ & 0.155 \\
\hline Insufficient sunlight during the day $(\mathrm{N}=663)$ & $79(75.2)$ & $\begin{array}{l}1.9(1.19- \\
3.06)\end{array}$ & 0.008 \\
\hline Light pollution at night $(\mathrm{N}=663)$ & $28(73.7)$ & $\begin{array}{l}1.6(0.76- \\
3.34)\end{array}$ & 0.213 \\
\hline Too hot in summer or too cold in winter $(\mathrm{N}=664)$ & $124(69.7)$ & $\begin{array}{l}1.43(0.99- \\
2.07)\end{array}$ & 0.055 \\
\hline No air conditioner, fan, or heater $(N=663)$ & $11(91.7)$ & $\begin{array}{l}6.28(0.83- \\
47.61)\end{array}$ & 0.075 \\
\hline High humidity or leaking/dripping water $(N=663)$ & $139(70.9)$ & $\begin{array}{l}1.59(1.11- \\
2.28)\end{array}$ & 0.012 \\
\hline $\begin{array}{l}\text { Old or dirty walls, furniture, or belongings (besides } \\
\text { having bedbugs) }(\mathrm{N}=663)\end{array}$ & $125(73.5)$ & $\begin{array}{l}1.84(1.25- \\
2.7)\end{array}$ & 0.002 \\
\hline Second-hand furniture $(N=663)$ & $39(86.7)$ & $\begin{array}{l}3.99(1.67- \\
9.54)\end{array}$ & 0.002 \\
\hline $\begin{array}{l}\text { Wallpaper or ceiling paint peeling, or rebar showing } \\
\text { through walls }(N=664)\end{array}$ & $90(76.3)$ & $\begin{array}{l}2.09(1.32- \\
3.31)\end{array}$ & 0.002 \\
\hline Poor ventilation ( $\mathrm{N}=662)$ & $64(68.8)$ & $\begin{array}{l}1.3(0.81- \\
2.07)\end{array}$ & 0.275 \\
\hline Strange odour $(N=663)$ & $65(74.7)$ & $\begin{array}{l}1.79(1.07- \\
2.99)\end{array}$ & 0.026 \\
\hline
\end{tabular}




\begin{tabular}{|c|c|c|c|}
\hline & $\begin{array}{l}\text { Weighted bedbug } \\
\text { infestation (\%) }\end{array}$ & $\begin{array}{l}\text { OR }(95 \% \\
\mathrm{Cl}) *\end{array}$ & $\begin{array}{l}\mathrm{p}- \\
\text { value* }\end{array}$ \\
\hline Rat infestation $(\mathrm{N}=663)$ & $44(83)$ & $\begin{array}{l}2.87(1.39- \\
5.92)\end{array}$ & 0.004 \\
\hline Noisy or have noise problems $(\mathrm{N}=663)$ & $72(72.7)$ & $\begin{array}{l}1.66(1.03- \\
2.66)\end{array}$ & 0.037 \\
\hline Stranger or new resident moved in $(\mathrm{N}=664)$ & $31(66)$ & $\begin{array}{l}1.13(0.6- \\
2.13)\end{array}$ & 0.695 \\
\hline $\begin{array}{l}\text { Housing cleanliness issues (besides having } \\
\text { bedbugs) }(N=662)\end{array}$ & $50(87.7)$ & $\begin{array}{l}4.26(1.93- \\
9.4)\end{array}$ & $<.001$ \\
\hline Residential unit originally had bedbugs $(\mathrm{N}=664)$ & $19(86.4)$ & $\begin{array}{l}3.65(1.06- \\
12.53)\end{array}$ & 0.04 \\
\hline $\begin{array}{l}\text { Presence of bedbugs in neighbouring residential } \\
\text { units }(N=663)\end{array}$ & 75 (89.3) & $\begin{array}{l}5.29(2.63- \\
10.64)\end{array}$ & $<.001$ \\
\hline Presence of bedbugs on the streets $(N=663)$ & $98(80.3)$ & $\begin{array}{l}2.77(1.72- \\
4.48)\end{array}$ & $<.001$ \\
\hline
\end{tabular}

${ }^{*} \mathrm{~N}=663$ for all bivariate regression models.

Socio-demographic variables significantly associated with bedbug infestation are age $(p=0.006)$, education level $(p<0.001)$, monthly household income $(p<0.001)$, and region $(p=0.013)$. Sex is not significantly associated with bedbug infestation. Age has a positive trend with percentage of bedbug infestation while education level and monthly household income have negative trends. Only those in income groups $<$ HKD10,000 $(p=0.001)$ and HKD10,000-30,000 $(p<0.001)$ have significantly greater ORs compared to the reference category, $>H K D 80,000$. Thus, monthly household income was recoded into a dichotomous variable "monthly household income $\leq$ HKD30,000" $(p<0.001)$ and included in the multivariate regression. Compared to living in the New Territories region, living in the Hong Kong Island region is not significantly different, but living in the Kowloon region $(p=0.005)$ has significantly greater OR of bedbug infestation.

Crowded household $(p<0.001)$ and the variables that were used to derive it i.e. feeling crowded $(p=$ $0.004)$, living floor area per capita $\leq 120 \mathrm{ft}^{2} /$ person $(p=0.024)$, living floor area $(p=0.001)$, and household size $(p<0.001)$ are significantly associated with bedbug infestation. There is a negative trend between living floor area and percentage of bedbug infestation (Fig. 2). Those living in $<300 \mathrm{ft}^{2}(\mathrm{p}=$ $0.005)$ have significantly greater OR compared to the reference category, $>900 \mathrm{ft}^{2}$. However, the relationship between household size and percentage of bedbug infestation appears to peak at the extremes (Fig. 3). When dividing the upper bounds of the intervals for living floor area by that of household size to compute living floor area per capita, the negative trend with percentage of bedbug infestation is retained (Fig. 4). 
The housing types significantly associated to bedbug infestation are public rental housing $(p<0.001)$, home ownership scheme $(p=0.011)$, private housing (whole unit) $(p=0.004)$, and subdivided flats $(p=$ 0.017). Public rental housing and subdivided flats significantly increases the odds of bedbug infestation whereas home ownership scheme and private housing (whole unit) significantly decreases its odds.

Participants who report more dilapidated housing features are significantly more likely to report bedbug infestation ( $\mathrm{OR}=1.28,95 \% \mathrm{Cl} 1.18-1.39, \mathrm{p}<0.001)$ (Fig. 5). The dilapidated housing features that significantly increases the odds of bedbug infestation are insufficient sunlight during the day $(p=0.008)$ (Fig. 6); high humidity or leaking/dripping water $(p=0.012)$ (Fig. 7); old or dirty walls, furniture, or belongings $(p=0.002)$ (Fig. 8); second-hand furniture $(p=0.002)$; wallpaper or ceiling paint peeling, or rebar showing through walls $(p=0.002)$ (Figs. 7 and 9$)$; strange odour $(p=0.026)$; rat infestation $(p=$ $0.004)$; noisy or have noise problems $(p=0.037)$; housing cleanliness issues (besides having bedbugs) ( $p$ $<0.001$ ) (Fig. 10); residential unit originally had bedbugs $(p=0.04)$; presence of bedbugs in neighbouring residential units $(p<0.001)$; and presence of bedbugs on the streets $(p<0.001)$.

\section{Multivariate analysis}


Table 3

Final model predicting bedbug infestation

\begin{tabular}{|lll|}
\hline Final model $(\mathbf{N}=663)$ & OR $(95 \%$ Cl $)$ & p-value \\
\hline Age $(\geq 65=$ ref.) & $1.26(0.63-2.5)$ & 0.007 \\
\hline $0-24$ & $1.92(0.98-3.75)$ & 0.056 \\
\hline $25-44$ & $2.53(1.3-4.91)$ & 0.006 \\
\hline $45-64$ & & $<0.001$ \\
\hline Education level (Tertiary education = ref.) & $9.43(3.12-28.44)$ & $<0.001$ \\
\hline Primary education or below & $1.49(1-2.22)$ & 0.051 \\
\hline Secondary education & $1.69(1.15-2.5)$ & 0.008 \\
\hline Monthly household income $\leq$ HKD30,000 & $1.55(1.06-2.28)$ & 0.024 \\
\hline Crowded household & $16.53(1.01-269.72)$ & 0.049 \\
\hline Subdivided flats & $2.97(1.16-7.58)$ & 0.023 \\
\hline Second-hand furniture & $2.66(1.13-6.25)$ & 0.024 \\
\hline Housing cleanliness issues (besides having bedbugs) & $3.32(1.57-7.04)$ & 0.002 \\
\hline Presence of bedbugs in neighbouring residential units & $1.9(1.12-3.23)$ & 0.018 \\
\hline Presence of bedbugs on the streets & $0.35(0-0)$ & 0.002 \\
\hline Constant & & \\
\hline
\end{tabular}

Table 3 shows the final model. Socio-demographic factors entered into the final model were age $(p=$ $0.007)$, education level $(p<0.001)$, and monthly household income $\leq$ HKD30,000 $(O R=1.69,95 \% \mathrm{Cl}$ $1.15-2.5, p=0.008$ ). Compared to those aged $\geq 65$, the younger age groups $0-24$ and $25-44$ do not have significantly different $\mathrm{ORs}$, but those aged $45-64(\mathrm{OR}=2.53,95 \% \mathrm{Cl} 1.30-4.91, \mathrm{p}=0.006)$ have significantly greater OR of bedbug infestations. Those with primary education or below $(\mathrm{OR}=9.43,95 \% \mathrm{Cl}$ $3.12-28.44, p<0.001$ ) have significantly greater OR of bedbug infestations compared to tertiary education.

Housing factors entered into the final model were crowded household $(\mathrm{OR}=1.55,95 \% \mathrm{Cl} 1.06-2.28, \mathrm{p}=$ 0.024); subdivided flats $(\mathrm{OR}=16.53,95 \% \mathrm{Cl} 1.01-269.72, \mathrm{p}=0.049)$, second-hand furniture $(\mathrm{OR}=2.97$, $95 \% \mathrm{Cl} 1.16-7.58, \mathrm{p}=0.023)$; housing cleanliness issues (besides having bedbugs) $(\mathrm{OR}=2.66,95 \% \mathrm{Cl}$ $1.13-6.25, p=0.024)$; presence of bedbugs in neighbouring residential units $(\mathrm{OR}=3.32,95 \% \mathrm{Cl} 1.57-$ $7.04, p=0.002)$; and presence of bedbugs on the streets $(O R=1.9,95 \% \mathrm{Cl} 1.12-3.23, p=0.018)$. They are independent housing risk factors for bedbug infestations. 
The final model is able to correctly predict $70.6 \%$ of bedbug infestations. The omnibus test of model coefficient for the final model is significant $(p<0.001)$, it is better at predicting bedbug infestations compared to the null model. The Cox and Snell, and Nagelkerke R square of the final model is 0.178 and 0.244 respectively. The Hosmer-Lemeshow test is not significant $(p=0.597)$, there is no violation of the goodness-of-fit assumption. Additional file 2 shows that the results for multicollinearity diagnostics of the final model are below the thresholds, $\mathrm{VIF}<3$ and $|\mathrm{r}|<0.7$, there is no evidence of multicollinearity.

\section{Discussion}

This is the first empirical study to investigate the bedbug issue and its associated housing risk factors in Hong Kong.

\section{Crowded household}

This study finds that crowded household is a more important factor for bedbug infestations than household size. The data from this study shows a nonlinear relationship between household size and the percentage of bedbug infestation (Fig. 3), however living floor area per capita is linear (Fig. 4).

Furthermore, crowded household and the variables that it was computed from i.e. feeling crowded, living floor area, and household size were all considered for inclusion in the final model using the forward conditional method for variable selection, but only crowded household was entered.

This study disagrees with Gounder et al.'s 2014 findings that household size is a more important factor than crowdedness (29). The disagreement may be due to differences in study design and methodology. Unlike this study, Gounder et al. 2014 defined crowded housing as having $\geq 2$ household members for every living room and bedroom and did not measure the living floor area of the participants.

It is the crowdedness of the living situation which facilitates the propagation of bedbug infestations as human hosts become accessible by living in close proximity (5).

\section{Housing type}

Living in subdivided flats is a risk factor for bedbug infestation. Subdivided flats are formed from the splitting of a residential unit into two or more subdivisions, thus subdivided units often neighbour several others $(23,30)$. Over $50 \%$ of subdivided flats are located in the Kowloon region (30), this coincides with the choropleth map showing that the number of self-reported bedbug cases are concentrated in the Kowloon region (Fig. 1). Subdivided flats are usually crowded and have many dilapidated housing features, its marginalised residents often possess many health related risk factors and socioeconomic disadvantages $(22,23,31,32)$. In 2016, households living in subdivided flats have median living floor area per capita of $56.5 \mathrm{ft}^{2}$ and median monthly household income of HKD13,500, both are lower than their respective medians for all domestic households (30). Other studies have found similar results, that living in poor neighbourhoods and buildings with many adjacent housing units facilitate the spread of bedbugs $(5,6,20)$. Bedbug infestation in subdivided flats have been reported to be a cause for other social issues 
such as people sleeping at 24 -hour fast food restaurant to avoid bedbug bites $(25,33)$. The combination of building and resident characteristics of subdivided flats make their occupants especially vulnerable to bedbug infestations.

\section{Dilapidated housing features}

This study finds that participants who report more dilapidated housing features are more likely to report bedbug infestations (Fig. 5). This study has identified having second-hand furniture, housing cleaning issues (besides having bedbugs), presence of bedbugs in neighbouring residential units, and presence of bedbugs on the streets to be independently associated with bedbug infestations.

Second-hand furniture has been suggested as a risk factor in other studies as they may harbour bedbugs from the previous owner $(5,6,20,29,34)$. Housing cleanliness issues may allow bedbugs to hide and be difficult to detect and eradicate which agrees with previous literature $(5,6,7)$.

Having bedbugs in neighbouring residential units and on the streets may indicate spreading of bedbugs in a community setting via hitchhiking or egress points such as cracks in walls or electrical conduits. Sheele et al. 2019 found that knowing someone with bedbugs is also a risk factor for bedbug infestation (35). This complicates bedbug management as bedbugs may return from the wider community, even if adjacent neighbouring units are treated for bedbugs. Addressing bedbugs may require the collective efforts of the wider community, not just the neighbourhood or individuals.

\section{Socio-demographics}

Having higher education level is a protective factor against bedbug infestation, it may reflect knowledge on bedbug infestation management or the ability to access such information. Older adults (45-64) are at greater risk since they are more active, thus are more likely to be in contact with infested places or persons, facilitating the spread of bedbugs $(20,35)$. This study finds that the elderly $(\geq 65)$ has the greatest proportion of bedbug infestation, they may be more likely to suffer from disabilities and financial difficulties resulting in their inability to maintain household cleanliness and not afford bedbug management services $(29,31)$. Having monthly household income $\leq$ HKD30,000 is a risk factor for bedbug infestation. In comparison, the 2019 median monthly household income of all economically active households in Hong Kong is HKD35,500 (16), and the typical cost of hiring exterminators ranges from HKD3,000 to HKD30,000. Low-income households may not afford to hire bedbug exterminators or replace infested furniture and personal belongings. Committing to these costs may result in perpetual poverty as bedbugs may return, requiring multiple treatments (5). Furthermore, low-income households are more likely to participate in risky behaviours such as trading second-hand furniture or using communal laundries $(5,20,29)$.

\section{Limitations}

Although age and sex weighting were applied to the analysis, the sample may be non-representative of the Hong Kong population as the sampling method used was volunteer sampling using online selfreported questionnaires. Responses from disadvantaged or marginalised groups with limited internet 
access such as primary education or below, elderly ( $\geq 65$ year olds), and occupants of subdivided flats may have been barred from participating, resulting in the reduced representativeness of these groups and their larger confidence intervals (36). Furthermore, there was no way to confirm the existence of bedbug infestations or any of the participants responses, except for a few cases $(N=7)$ who underwent follow-up visits.

Online data collection made it difficult to comprehensively evaluate the participants' housing situation. The presence of certain housing factors depended on the participant's subjective view of their existence, for example the same housing unit may be considered to have housing cleanliness issues by one participant but acceptable to another. Participants selected dilapidated housing features from a list, although an "others (please specify)" option was available, protective factors were not investigated.

Although steps were taken to minimise the erroneous recognition of bedbugs by providing a picture on the questionnaire to remind them of its appearance, bedbug sightings by older participants may be inaccurately reported since previous studies have found that the elderly ( $>60$ year olds) are more likely to wrongly identify bedbugs from a picture compared to younger people in self-reported questionnaires (35). Furthermore, participants may be predominantly reporting adult bedbug sightings and failing to identify smaller bedbugs in earlier instars, resulting in under-reporting (37).

Social desirability may skew the responses towards lower reported bedbug infestations and housing risk factors since having them are associated with negative stereotypes such as being poor, uneducated, and unhygienic $(14,26)$. However, people who do not have bedbugs may not report their situation since they may find the voluntary online questionnaire irrelevant to them, and vice versa for those who have bedbugs, resulting in an arbitrarily higher percentage of reported bedbug infestations.

The cross-sectional study design was unable to establish the temporal sequence of events between bedbug infestations and the variables being investigated. Socio-demographic and housing factors are likely to have existed before the occurrence of the bedbug infestation. However, having bedbug infestations may result in some of these factors arising. For example, the signs of bedbugs (their faeces, carcass, and exuviae on walls or furniture) may be interpreted as having housing cleanliness issues.

Crowded and dilapidated housing features are likely to be manifested similarly in other settings, however certain features of Hong Kong's housing situation such as the housing related policies, housing types, and their specific building features may limit the generalisability of the results to other countries.

\section{Policy recommendations}

There needs to be a shift in viewing bedbug infestations as a personal hygiene to a public health issue. Efforts and policies should be focused on alleviating crowded and dilapidated housing and providing adequate standards of living. This will directly address the global bedbug resurgence by removing its environmental facilitators and reverberate improvements to other aspects of life related to housing such as employment, education, and health. Efforts and policies should also prioritise vulnerable groups such 
as the elderly, low education level, low-income groups, and occupants of at-risk housing types such as subdivided flats.

Faced with the global threat of bedbug resurgence, simultaneous top-down and bottom-up approaches are required. Examples of top-down approaches are anti-poverty policies, increasing the supply and shortening the waiting time of public housing, and relief and cleaning services for those in deprived housing $(22,31,32,38)$. Bottom-up approaches focus on empowering and building resilience of the public to address bedbugs themselves, especially vulnerable groups at risk or already suffering from bedbugs. Educating low-income households to identify the early signs of bedbug and to self-manage using integrated pest management (IPM) or affordable non-chemical control methods when infestation rates are still low prevents infestations from exacerbating and spreading, thus mitigates the expensive costs of hiring exterminators or replacing furniture and personal belongings $(39,40,41,42,43,44)$.

\section{Conclusion}

Crowded household, subdivided flats, and dilapidated housing are risk factors for bedbug infestations. To better control bedbug infestations, there needs to be a shift from viewing infestations as a personal hygiene to a public health issue. Efforts and policies should focus on addressing the housing risk factors identified in this study and prioritise vulnerable groups such as the elderly, low education level, lowincome groups, and occupants of subdivided flats.

\section{Abbreviations}

\begin{tabular}{ll} 
CI & Confidence interval \\
\hline CUHK & The Chinese University of Hong Kong \\
\hline HKD & Hong Kong Dollar \\
\hline HKSAR & Hong Kong Special Administrative Region \\
\hline IBM & International Business Machines Corporation \\
\hline OR & Odds ratio \\
\hline ref. & Reference category \\
\hline SBREC & Survey and Behavioural Research Ethics Committee \\
\hline SPSS 24 & Statistical Product and Service Solutions version 24 \\
\hline USD & United States Dollar \\
\hline US EPA & United States Environmental Protection Agency \\
\hline VIF & Variance Inflation Factors \\
\hline Ir| & Absolute value of the Pearson correlation coefficient
\end{tabular}




\section{Declarations}

\section{Ethics approval}

This research has been approved by the Survey and Behavioural Research Ethics Committee (SBREC), of CUHK [Reference No. SBRE-19-778].

\section{Ethics and consent to participate}

Written informed consent was obtained from all participants in digital form. After accessing the link to the online survey, participants were shown a statement of consent which explains the purpose of the study, type of questions to be asked, eligibility criteria, data security, participant rights, and risks involved. The questions to the online questionnaire were only shown after participants voluntarily select "Agree" then "next".

\section{Consent for publication}

Not applicable

\section{Availability of data and materials}

The dataset used in this research is available in as an additional file (Additional file 3).

\section{Competing interests}

The authors declare that they have no competing interests

\section{Funding}

This study has received no funding.

\section{Author's contributions}

EHCF performed data collection, data analysis, and manuscript writing. HW conceptualized and coordinated the research. SWC, JHLH, HML, and SMC provided scientific knowledge. RYC and SYW provided public health knowledge about bedbugs and research design on data collection and data analysis. All authors read, edited, and approved the final manuscript. 


\section{Acknowledgements}

This study is part of a larger project entitled "Providing low-income residents with safe, effective, affordable and sustainable solutions in tackling bed bug problems" conducted by the Chinese University of Hong Kong (CUHK) Anti-Bedbug Research Action Group, composed of professors and students formed in January 2019. The authors extend their sincerest gratitude to the group of student volunteers from this group for their efforts in data collection.

\section{References}

1. Cannet A, Akhoundi M, Berenger JM, Michel G, Marty P, Delaunay P. A review of data on laboratory colonies of bed bugs (Cimicidae), an insect of emerging medical relevance. Parasite. 2015 June; 22(21).

2. USEPA. Joint statement on bed bug control in the United States from the U.S. Centers for Disease Control and Prevention (CDC) and the U.S. Environmental Protection Agency (EPA). [Online].; 2010 [cited 2020 April 18]. Available from: https://stacks.cdc.gov/view/cdc/21750.

3. Benoit JB. Stress Tolerance of Bed Bugs: A Review of Factors That Cause Trauma to Cimex lectularius and C. Hemipterus. Insects. 2011 April; 2(2): p. 151-172.

4. Delaunay P, Blanc V, Giudice PD, Levy-Bencheton A, Chosidow O, Marty P, et al. Bedbugs and Infectious Diseases. Clinical Infectious Diseases. 2011 January; 52(2): p. 200-210.

5. Harlan HJ, Faulde MK, Baumann GJ. Public Health Significance of Urban Pests: Bedbugs (4). Copenhagen, Denmark: World Health Organization; 2008.

6. Davies TGE, Field LM, Williamson MS. The re-emergence of the bed bug as a nuisance pest: implications of resistance to the pyrethroid insecticides. Medical and Veterinary Entomology. 2012 September; 26(3): p. 241-254.

7. Zorrilla-Vaca A, Silva-Medina MM, Escandón-Vargas K. Bedbugs, Cimex spp.: their current world resurgence and healthcare impact. Asian Pacific Journal of Tropical Disease. 2015 May; 5(5): p. 342352.

8. Thomas I, Kihiczak GG, Schwartz RA. Bedbug bites: a review. International Journal of Dermatology. 2004 June; 43(6): p. 430-433.

9. Doggett SL, Russell R. Bed bugs - What the GP needs to know. Australian family physician. 2009 November; 38(11): p. 880-884.

10. Parola P, Izri A. Bedbugs. The new england journal of medicine. 2020 June; 382: p. 2230-2237.

11. deShazo RD, Feldlaufer MF, Mihm MCJr, Goddard J. Bullous Reactions to Bedbug Bites Reflect Cutaneous Vasculitis. The American Journal of Medicine. 2012 July; 125(7): p. 688-694.

12. Lai $O$, Ho D, Glick S, Jagdeo J. Bed bugs and possible transmission of human pathogens: a systematic review. Archives of Dermatological Research. 2016 October; 308(8): p. 531-538. 
13. Burton GJ. Bedbugs in Relation to Transmission of Human Diseases. Public Health Reports. 1963 June; 78(6): p. 513-524.

14. Ashcroft R, Seko Y, Chan LF, Dere J, Kim J, McKenzie K. The mental health impact of bed bug infestations: a scoping review. International Journal of Public Health. 2015 November; 60(7): p. 827837.

15. Scarpino SV, Althouse BM. Uncovering the hidden cost of bed bugs. Proceedings of the National Academy of Sciences of the United States of America. 2019 April; 116(15): p. 7160-7162.

16. Census and Statistics Department, HKSAR. Population and Household Statistics Analysed by District Council District 2019. 2020 March.

17. Wang C, Wen X. Bed Bug Infestations and Control Practices in China: Implications for Fighting the Global Bed Bug Resurgence. Insects. 2011 April; 2(2): p. 83-95.

18. Godfrey R, Julien M. Urbanisation and health. Clinical Medicine Journal. 2005 March; 5(2): p. 137141.

19. Eddy C, Jones SC. Bed Bugs, Public Health, and Social Justice: Part 1, A Call to Action. Journal of Environmental Health. 2011 April; 73(8): p. 8-14.

20. Ralph N, Jones HE, Thorpe LE. Self-Reported Bed Bug Infestation Among New York City Residents: Prevalence and Risk Factors. Journal of Environmental Health. 2013 August; 76(1): p. 38-45.

21. CBRE. Global Living Report 2020. [Online].; 2020 [cited 2020 August 1]. Available from: https://www.cbreresidential.com/uk/sites/uk-residential/files/CBREGlobal\%20Living_2020_Final.pdf.

22. Wong $\mathrm{H}$, Chan $\mathrm{Sm}$. The impacts of housing factors on deprivation in a world city: The case of Hong Kong. Social Policy and Administration. 2019 November; 53(6): p. 872-888.

23. Ho A. HKFP: The unlivable dwellings in Hong Kong and the minimum living space. [Online].; 2015 [cited 2020 September 3]. Available from: https://hongkongfp.com/2015/07/27/the-unlivabledwellings-in-hong-kong-and-the-minimum-living-space/.

24. Ng N. SCMP: Average living space for Hong Kong's poorest residents same as that of prisoners, survey reveals. [Online].; 2017 [cited 2020 September 3]. Available from: https://www.scmp.com/news/hong-kong/community/article/2117810/average-living-space-hongkongs-poorest-residents-same.

25. Ting V. SCMP: Bedbug infestations widespread in Hong Kong, study finds, with one expert warning of 'public health issue'. [Online].; 2019 [cited 2020 September 3]. Available from: https://www.scmp.com/news/hong-kong/health-environment/article/3030198/bed-bug-infestationswidespread-hong-kong-study.

26. Cheung R. SCMP: Is Hong Kong on the verge of a major bed bug epidemic? We talk to the experts and get some tips. [Online].; 2017 [cited 2020 September 4]. Available from: https://www.scmp.com/lifestyle/health/article/2098227/hong-kong-verge-major-bed-bug-epidemicwe-talk-experts-and-get-some. 
27. Faul F, Erdfelder E, Buchner A, Lang AG. Statistical power analyses using G*Power 3.1: Tests for correlation and regression analyses. Behavior Research Methods. 2009; 41(4): p. 1149-1160.

28. Dormann CF, Elith J, Bacher S, Buchmann CM, Carl G, Carré G, et al. Collinearity: a review of methods to deal with it and a simulation study evaluating their performance. Ecography. 2013 January; 36(1): p. 27-46.

29. Gounder P, Ralph N, Maroko A, Thorpe L. Bedbug Complaints among Public Housing Residents-New York City, 2010-2011. Journal of Urban Health: Bulletin of the New York Academy of Medicine. 2014 February; $91(6)$ : p. 1076-1086.

30. Census and Statistics Department, HKSAR. Thematic Report: Persons Living in Subdivided Units. 2016 Population By-census. 2018 January.

31. Li PKC. Policy Implications on Assistance for the "Caged Elderly" in Hong Kong. Journal of Health \& Social Policy. 2001 February; 12(4): p. 35-52.

32. Yau Y, Ho DCW. Exploring policy options to combat illegal microapartments in Hong Kong. Urbani izziv. 2017 December; 28(2): p. 83-95.

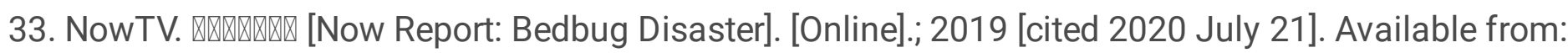
https://www.youtube.com/watch?v=fgABkTklbho.

34. Wang C, Saltzmann K, Chin E, Bennett GW, Gibb T. Characteristics of Cimex lectularius (Hemiptera: Cimicidae), Infestation and Dispersal in a High-Rise Apartment Building. Journal of Economic Entomology. 2010 February; 103(1): p. 172-177.

35. Sheele JM, Crandall CJ, Chang BF, Arko BL, Dunn CT, Negrete A. Risk Factors for Bed Bugs Among Urban Emergency Department Patients. Journal of Community Health. 2019 May; 44: p. 1061-1068.

36. Mascha EJ, Vetter TR. Significance, Errors, Power, and Sample Size: The Blocking and Tackling of Statistics. Anesthesia and Analgesia. 2018 February; 126(2): p. 691-698.

37. Sheele JM, Barrett E, Dash D, Ridge GE. Analysis of the life stages of Cimex lectularius captured within a medical centre suggests that the true numbers of bed bug introductions are under-reported. Journal of Hospital Infection. 2017 November; 97(3): p. 310-312.

38. WHO. Household Crowding (3). WHO Housing and Health Guidelines. 2018.

39. Alizadeh I, Jahanifard E, Sharififard M, Azemi ME. Effects of Resident Education and SelfImplementation of Integrated Pest Management Strategy for Eliminating Bed Bug Infestation in Ahvaz City, Southwestern Iran. Journal of Arthropod-Borne Diseases. 2020 April; 14(1): p. 68-77.

40. Cooper RA, Wang C, Singh N. Evaluation of a model community-wide bed bug management program in affordable housing. Pest Management Science. 2016 January; 72(1): p. 45-56.

41. Wang C, Saltzmann K, Bennett G, Gibb T. Comparison of Three Bed Bug Management Strategies in a Low-Income Apartment Building. Insects. 2012 April; 3(2): p. 402-409.

42. Wang C, Eiden A, Singh N, Zha C, Wang D, Cooper R. Dynamics of bed bug infestations in three lowincome housing communities with various bed bug management programs. Pest Management Science. 2018 June; 74(6): p. 1302-1310. 
43. Romero A, Sutherland AM, Gouge DH, Spafford H, Nair S, Lewis V, et al. Pest Management Strategies for Bed Bugs (Hemiptera: Cimicidae) in Multiunit Housing: A Literature Review on Field Studies. Journal of Integrated Pest Management. 2017 May; 8(1): p. 13; 1-10.

44. Bennett GW, Gondhalekar AD, Wang C, Buczkowski G, Gibb TJ. Using research and education to implementpractical bed bug control programs inmultifamily housing. Pest Management Science. 2016 January; 72(1): p. 8-14.

\section{Additional Files Details}

File name: Additional file 1

File format: Word Document.docx

Title: Online questionnaire design

Description: Word.docx version of the online questionnaire used in this study. The questions and responses are the same as the Google forms version.

File name: Additional file 2

File format: Word Document.docx

Title: Multicollinearity diagnostics variance inflation factors (VIF) and Pearson correlation coefficients ( $r$ )

Description: Results of the multicollinearity diagnostics of the final model presented in this report.

File name: Additional file 3

File format: Excel Workbook.xlsx

Title: Dataset

Description: Linelist dataset containing participants' responses used in data analysis. The first row is the variable name and corresponds to the variables presented in the results section, the spaces have been replaced with an underscore. In "Sheet 1", each row represnts a participant and each column a variable. Missing variables are entered as "999". The column labelled "case_weight_age_sex" contains the case weightings by age and sex. "Sheet 2 " shows the coding scheme for each variable.

\section{Figures}




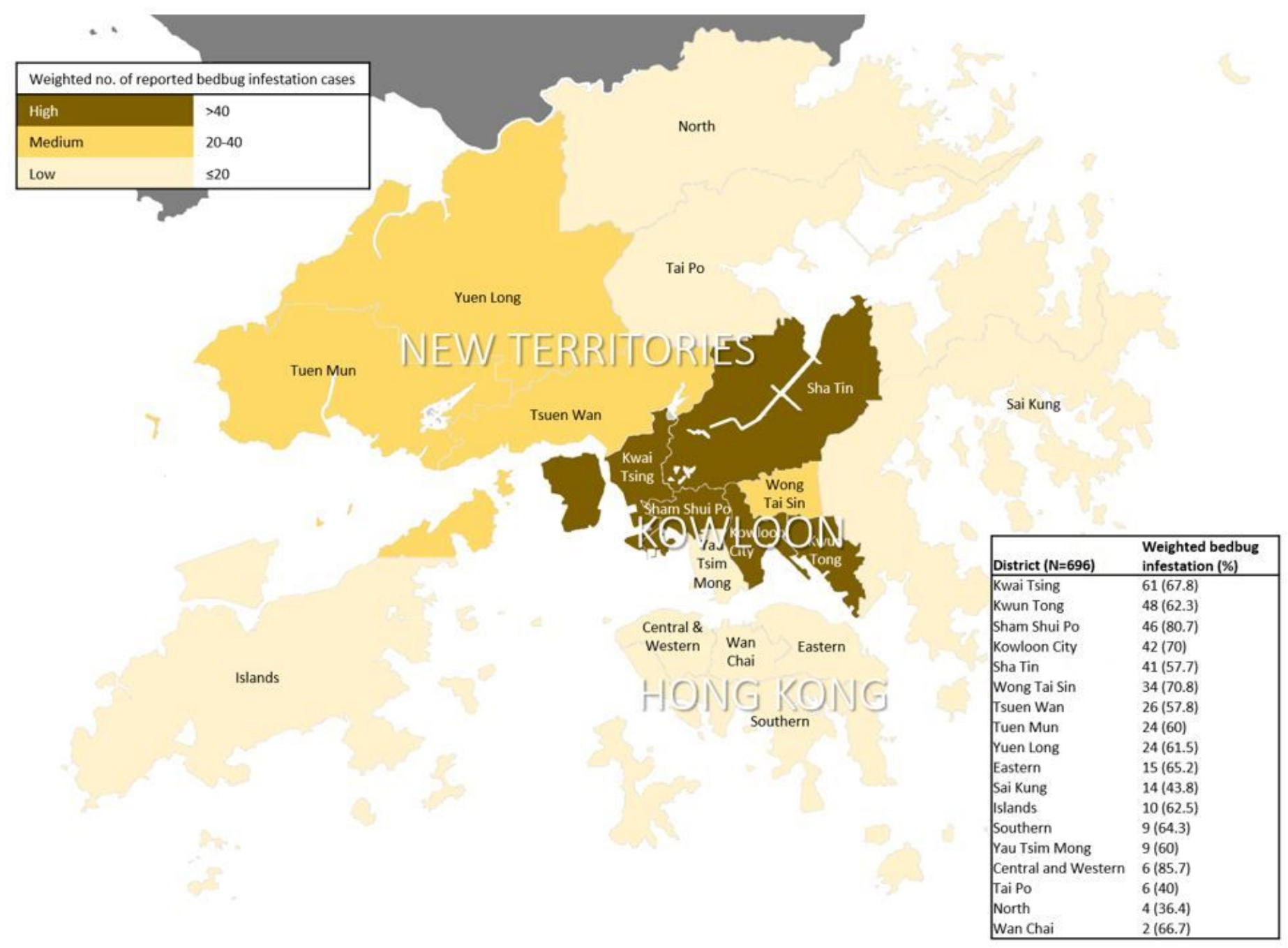

\section{Figure 1}

Distribution of bedbug cases by district Figure 1 was adapted from "Hong Kong 18 Districts Blank Map" by wahaha2005 and is licensed under Creative Commons Attribution-Share Alike 3.0 Unported license. Note: The designations employed and the presentation of the material on this map do not imply the expression of any opinion whatsoever on the part of Research Square concerning the legal status of any country, territory, city or area or of its authorities, or concerning the delimitation of its frontiers or boundaries. This map has been provided by the authors. 


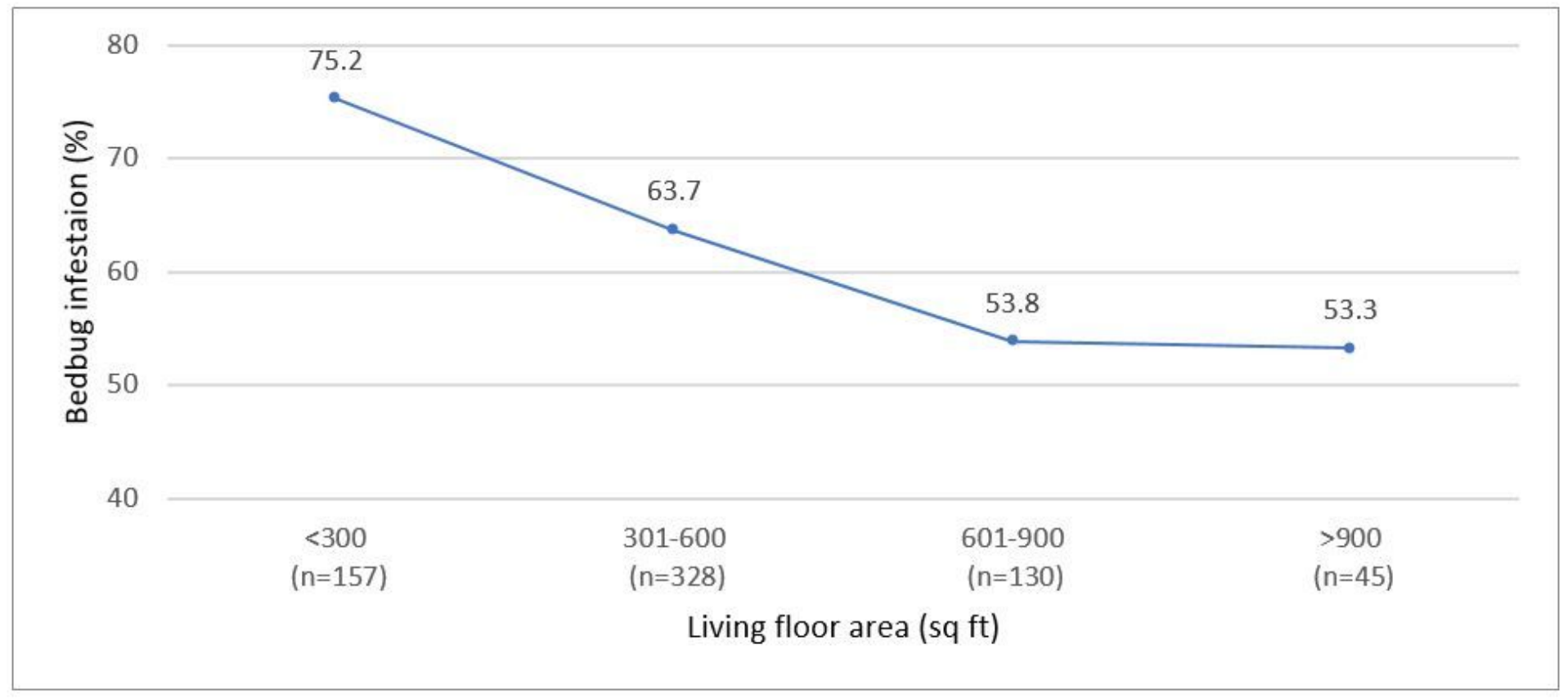

\section{Figure 2}

Living floor area and bedbug infestation $(\mathrm{N}=660)$

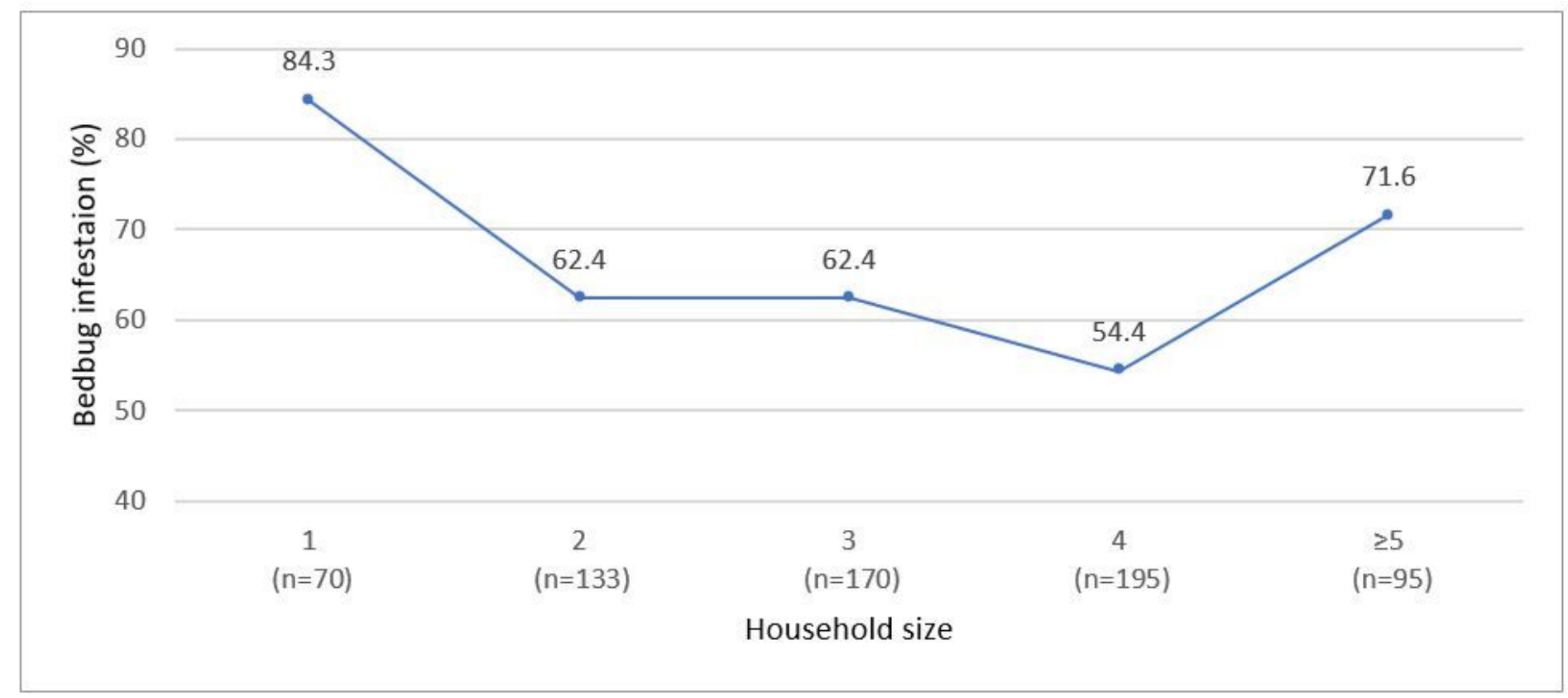

Figure 3

Household size and bedbug infestation $(\mathrm{N}=663)$ 


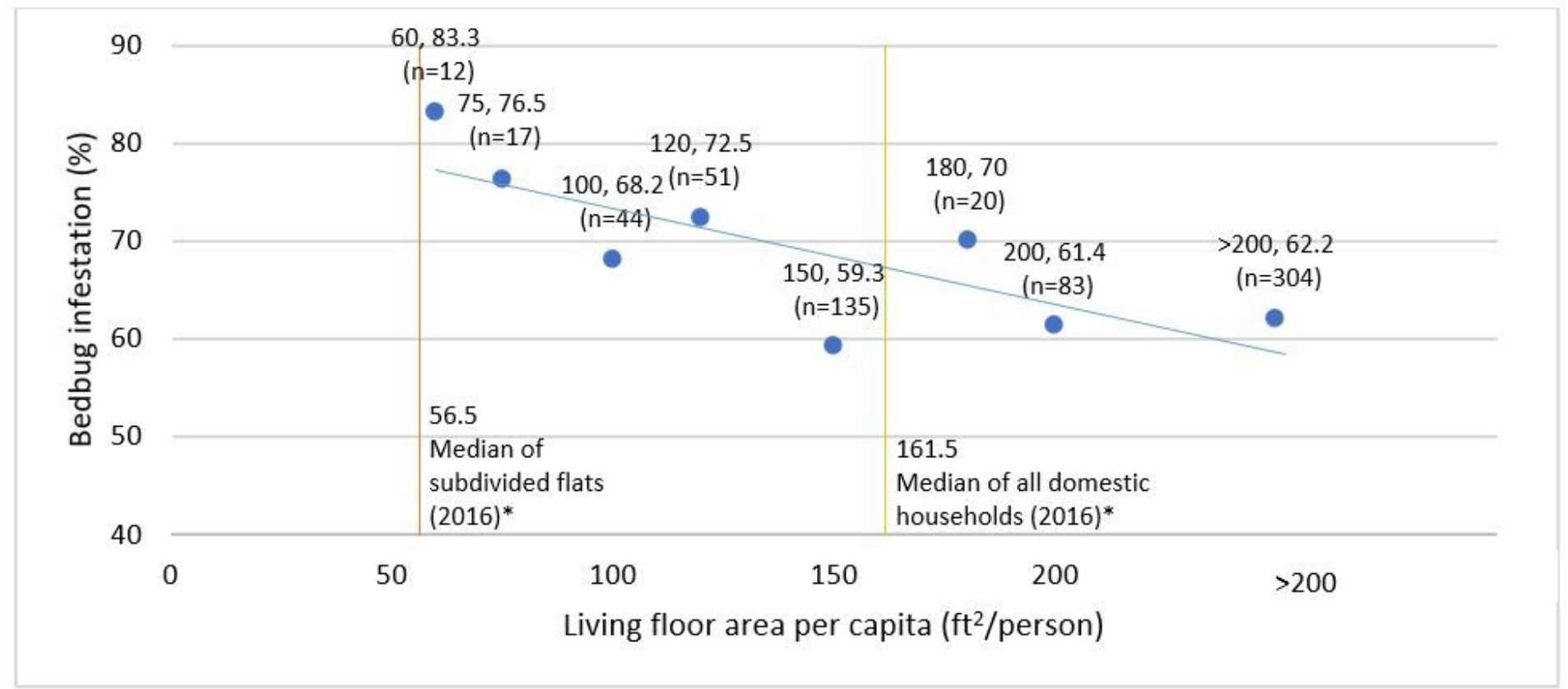

\section{Figure 4}

Living floor area per capita and bedbug infestation $(\mathrm{N}=666)$ *Median figures from the Census and Statistics Department, HKSAR (30).

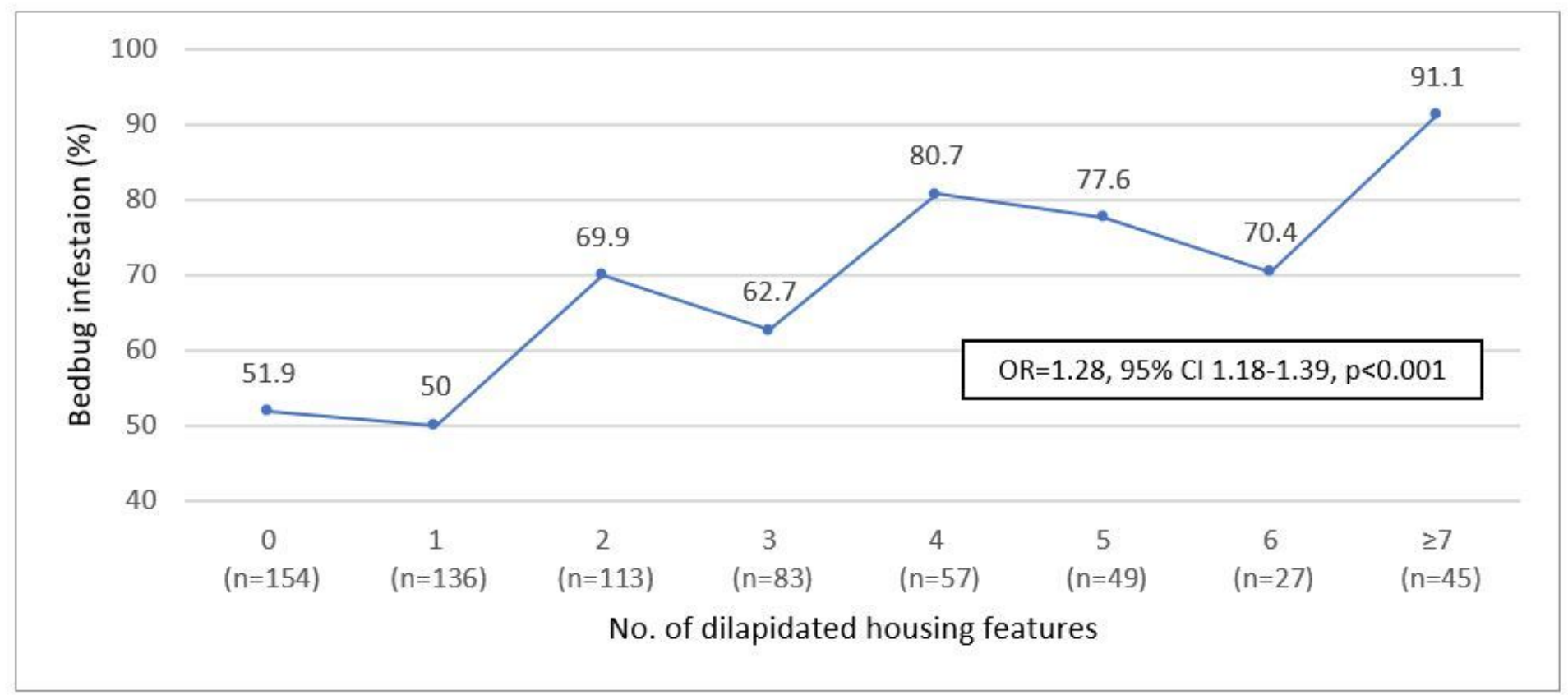

\section{Figure 5}

Number of dilapidated housing features and bedbug infestation $(\mathrm{N}=664)$ 


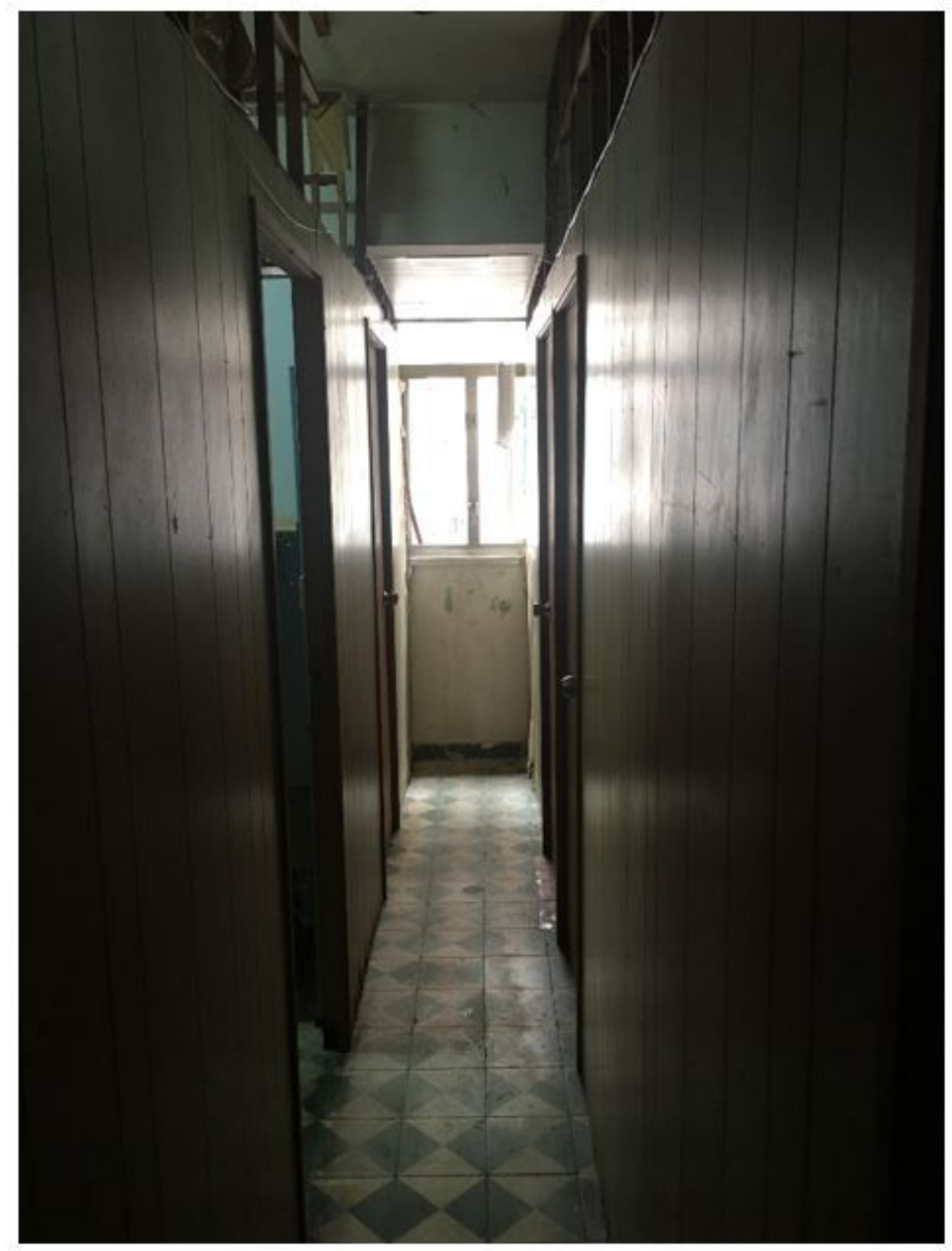

Figure 6

Darkened corridoor of a subdivided flat This figure belongs to us and was taken during the follow-up visits. 


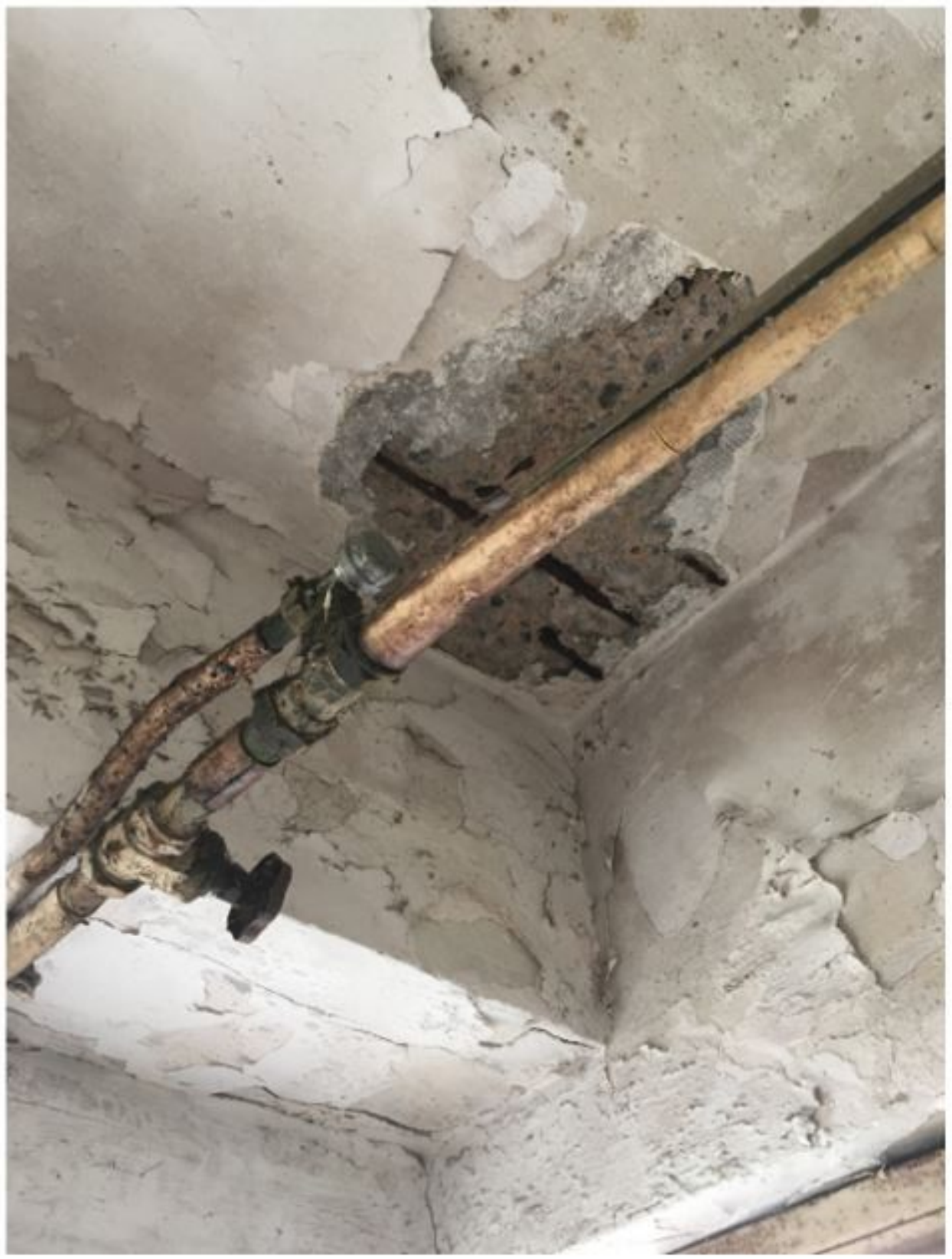

Figure 7

Ceiling paint peeling with rebar showing through walls above a rusty and leaking pipe This figure belongs to us and was taken during the follow-up visits. 


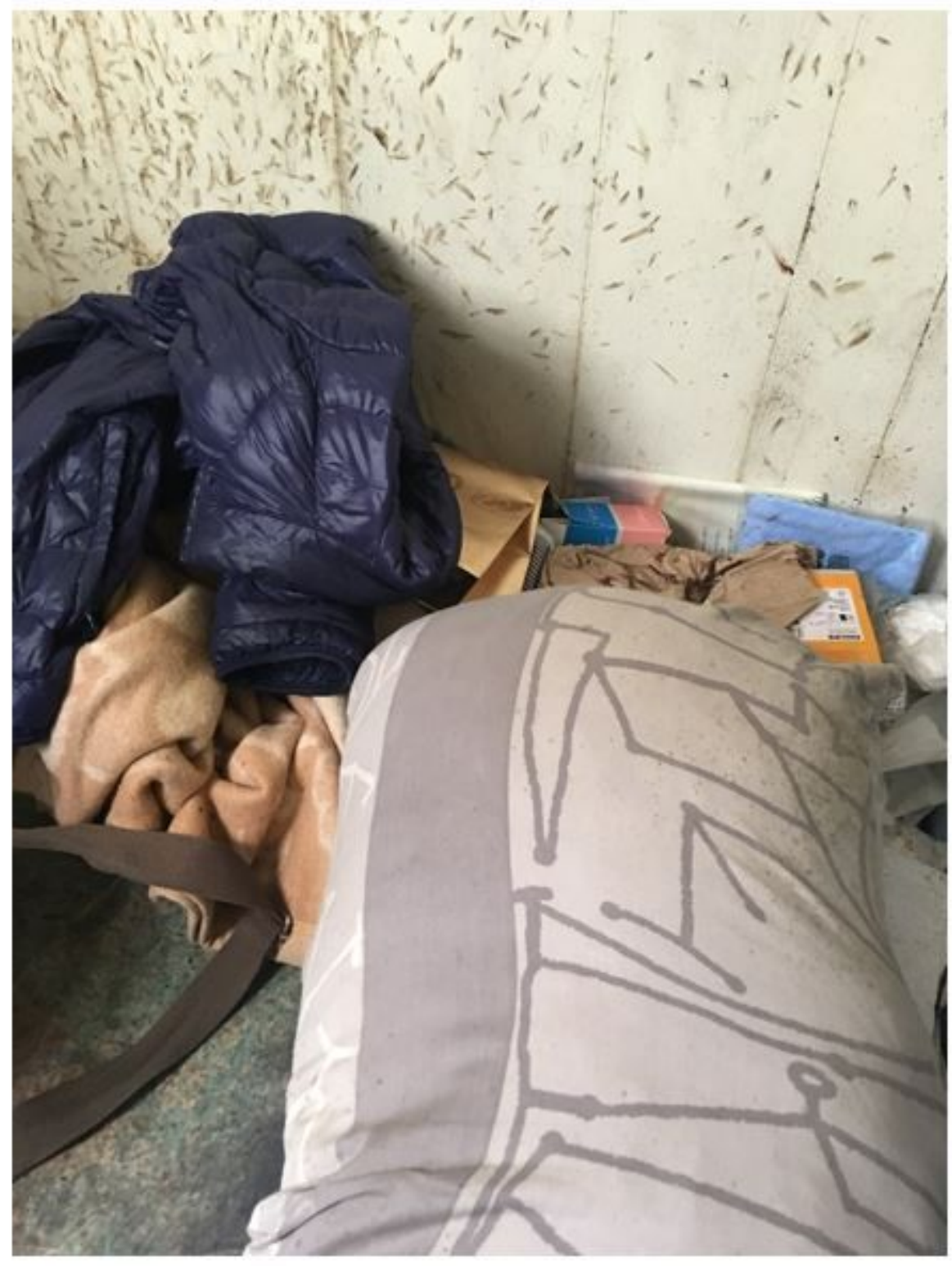

Figure 8

Sleeping area next to a wall covered with blood streaks from dead bedbugs This figure belongs to us and was taken during the follow-up visits. 


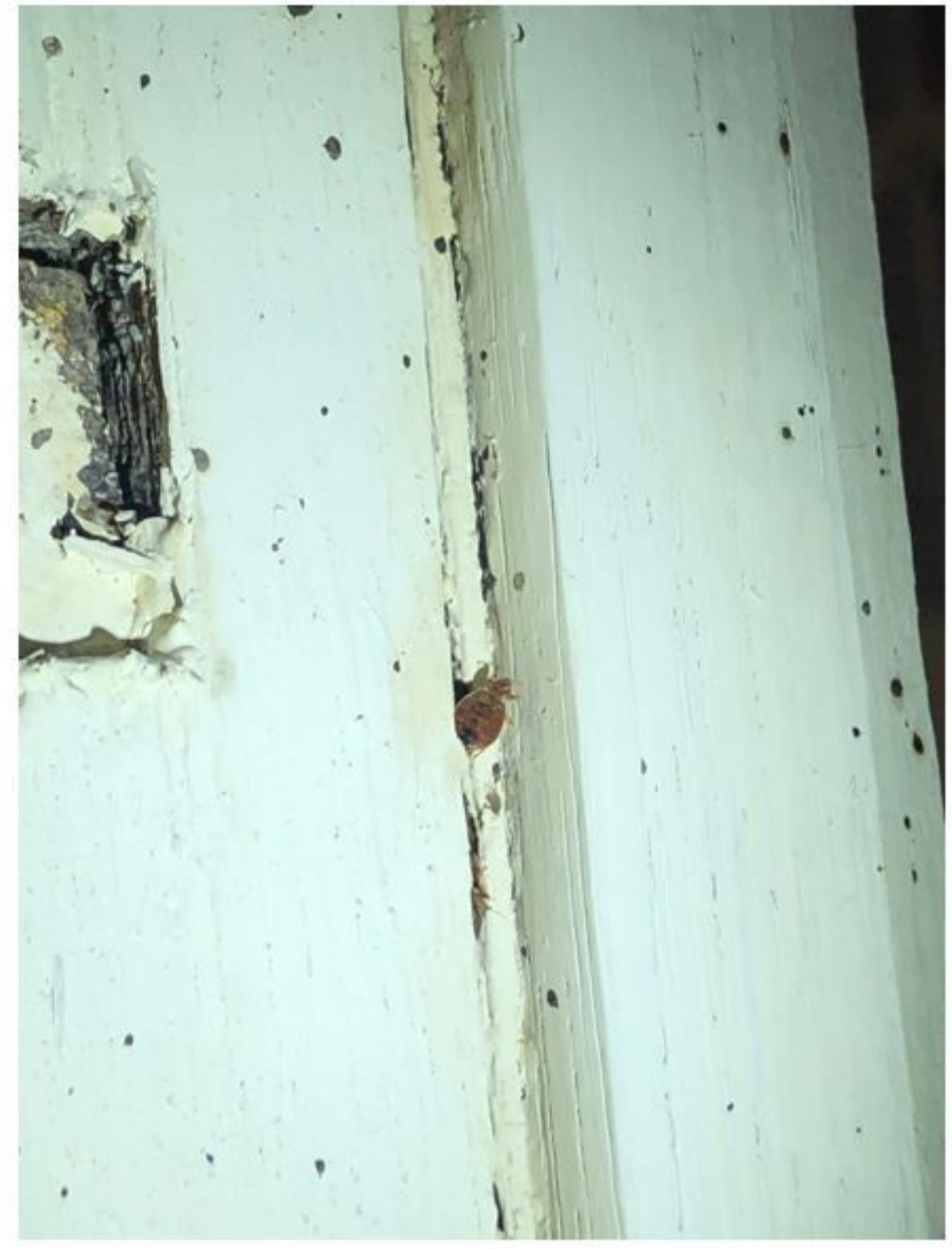

Figure 9

Bedbugs coming out and hidden in cracks in walls This figure belongs to us and was taken during the follow-up visits. 


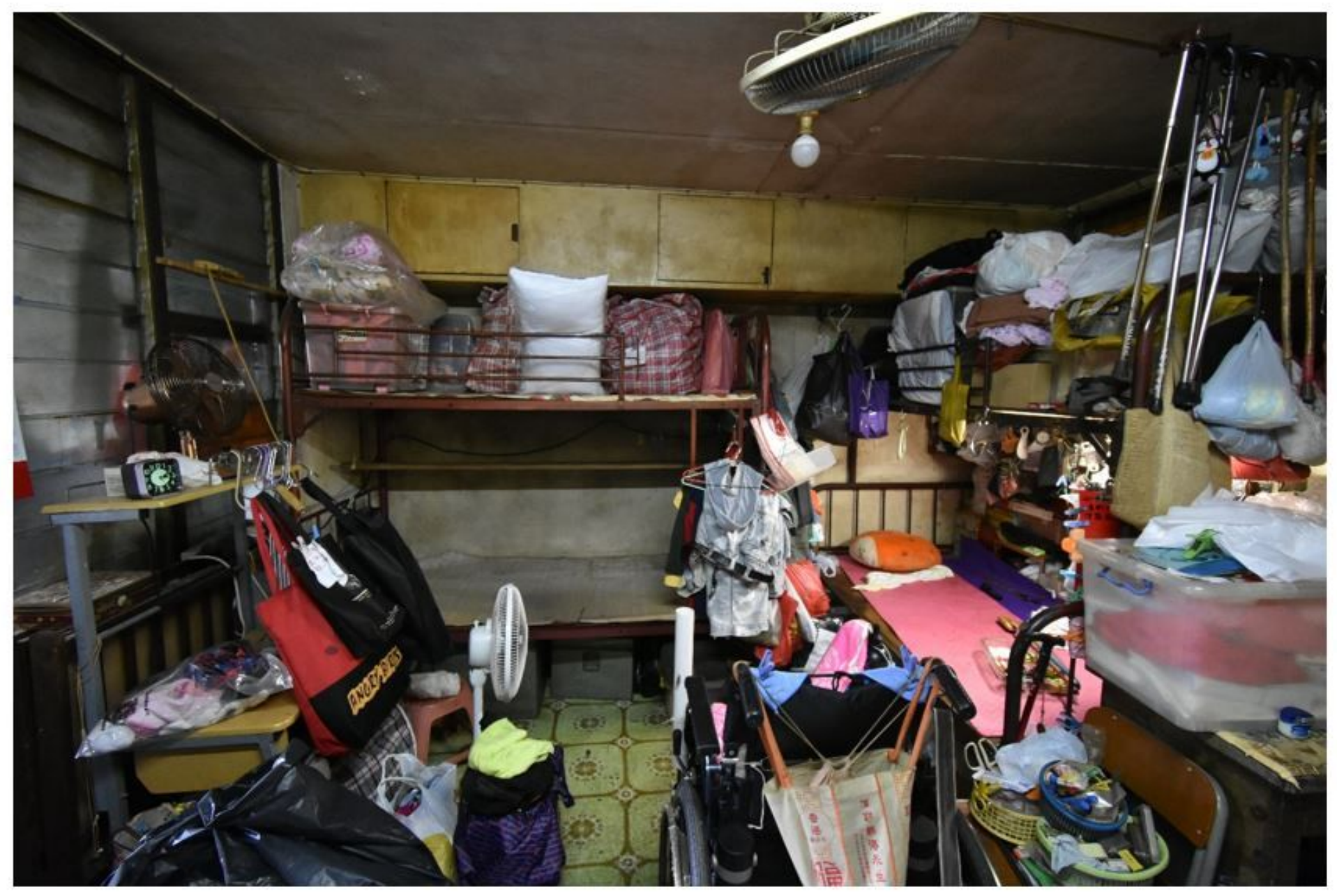

Figure 10

Cluttered public rental housing apartment This figure belongs to us and was taken during the follow-up visits.

\section{Supplementary Files}

This is a list of supplementary files associated with this preprint. Click to download.

- Additionalfile1.docx

- Additionalfile2.docx

- Additionalfile3.xlsx

- STROBEchecklist.docx 